\title{
Uphill and downhill water transport in rat glioma cells
}

\author{
Béatrice Rouzaire-Dubois` and Jean-Marc Dubois \\ CNRS, Institut de Neurobiologie Alfred Fessard-FRC2118, Laboratoire de Neurobiologie Cellulaire et Moléculaire-FRE 3295, \\ Gif sur Yvette, F-91198, France
}

\begin{abstract}
The cell water content determines the cell volume, which in turn controls numerous cellular functions. The mean volume of rat glioma cells was electronically measured under isotonic and anisotonic conditions. Two types of isotonic solutions were used containing either high or low concentrations of $\mathrm{NaCl}, \mathrm{KCl}$ or $\mathrm{N}$-methylglucamineCl. In low salt solutions, osmolarity was maintained constant by the addition of sucrose or mannitol. Anisotonicity was induced by changing the concentration of electrolytes. As expected, the cell volume increased when the concentration of electrolytes was decreased from a high $(165 \mathrm{mM})$ monovalent cation concentration. In contrast, the cell volume decreased when the concentration of electrolytes was decreased from a low $(85 \mathrm{mM})$ monovalent cation concentration. Reciprocally and unexpectedly, the cell volume increased during a hyperosmotic challenge when the initial cation concentration was low, whereas it decreased when the initial cation concentration was high. These opposite volume changes observed during similar anisotonic challenges but starting from different electrolyte concentrations provide the first evidence that $\mathrm{H}_{2} \mathrm{O}$ is not only passively transported (downhill) through aquaporins but also follows ion fluxes (uphill).
\end{abstract}

Key words: Cell volume - Ion channels - Osmotic stress $-\mathrm{H}_{2} \mathrm{O}$ flux

\section{Introduction}

Water transport through the plasma membrane of animal cells is a key feature of cell biology. Dependent on several physical parameters such as membrane tension and curvature, macromolecular crowding, extracellular osmolarity and osmolite composition, the cell volume is regulated and in turn controls numerous cellular functions including hormone and neuromediator release, cell proliferation, apoptosis and cell migration (Soroceanu et al. 1999; Lang et al. 2000; Najvirtova et al. 2003; Rouzaire-Dubois et al. 2004; Ernest et al. 2008; Okada et al. 2009). For these reasons, it is important to describe the different mechanisms that control the cell volume and that have often been underestimated.

During a hyposmotic stress, the cells swell because of a passive influx of water mainly mediated by specialised water pathways, the aquaporins. A few seconds after cell swelling, the cell volume starts slow recovery back towards its isos-

Correspondence to: Béatrice Rouzaire-Dubois, CNRS, Institut de Neurobiologie Alfred Fessard-FRC2118, Laboratoire de Neurobiologie Cellulaire et Moléculaire-FRE 3295, Gif sur Yvette, F-91198, France

E-mail: beatrice.rouzaire-dubois@nbcm.cnrs-gif.fr motic value by a process of regulatory volume decrease (RVD) whereby the cell size increase activates $\mathrm{K}^{+}-\mathrm{Cl}^{-}$co-transporters and $\mathrm{Cl}^{-}$and $\mathrm{K}^{+}$channels, inducing an efflux of $\mathrm{K}^{+}, \mathrm{Cl}^{-}$and osmotically obliged $\mathrm{H}_{2} \mathrm{O}$ (Hoffmann et al. 2009).

Unexpectedly during RVD, the cell volume can become smaller than it was before the hyposmotic challenge (Ernest et al. 2005; Rouzaire-Dubois et al. 2009). This over-regulation suggests that another unknown process is activated during a hyposmotic stress which, in addition to the classical RVD, induces cell shrinkage. In order to test this hypothesis, we electronically measured the mean cell volume of rat glioma cells under basal isotonic conditions at high and low salt concentrations compensated with sucrose or mannitol. In some cases, $\mathrm{NaCl}$ was substituted with $\mathrm{KCl}$ or $\mathrm{N}$-methylglucamineCl (NMGCl). In most cases hypo- and hypertonic challenges were obtained by changes in electrolyte concentrations.

Given that in most cells, the osmotically inactive volume corresponds to only a few percent of the total cell volume (Growe et al. 1995; Rouzaire-Dubois et al. 2004; Ernest et al. 2005), any change in cell volume mainly reflects the change in cell water content due to water fluxes. Moreover, it has been suggested that $\mathrm{H}_{2} \mathrm{O}$ could be transported against its initial osmotic gradient by $\mathrm{Na}^{+}-\mathrm{K}^{+}-2 \mathrm{Cl}^{-}$and $\mathrm{Na}^{+}$-glucose cotransporters (Hammann et al. 2005; Zeuthen et al. 2007). This 
hypothesis has been the object of an intense debate because $\mathrm{H}_{2} \mathrm{O}$ could be either uphill transported through co-transporters (Zeuthen and Zeuthen 2007) or passively transported due to an increase in intracellular osmolarity (Charron et al. 2006). However, neither of these interpretations can explain an efflux of water in the absence of glucose or in hypotonic conditions where these transporters are not activated. For the first time, we furnish experimental arguments for a transport of $\mathrm{H}_{2} \mathrm{O}$ against its osmotic gradient in association with passive ion fluxes likely through non selective channels.

\section{Materials and Methods}

The experiments were performed on C6 rat glioma cells at a temperature of $20-22^{\circ} \mathrm{C}$. The cells were cultured as previously described (Rouzaire-Dubois et al. 2004, 2009). The cells were trypsin-detached, pelleted at $100 \times g$ for $5 \mathrm{~min}$, resuspended and mechanically stirred in isotonic solutions for 15-20 min before anisotonic challenges. Isotonic solutions $\left(339 \pm 2 \mathrm{mOsm} \cdot \mathrm{kg}^{-1}, n=15\right)$ contained either $160 \mathrm{mM}$ $\mathrm{NaCl}$ or $80 \mathrm{mM} \mathrm{NaCl}+150 \mathrm{mM}$ sucrose or mannitol. In complementary experiments, $\mathrm{NaCl}$ was isosmotically substituted with $\mathrm{KCl}$ or $\mathrm{N}$-methylglucamineCl. In addition to theses ions, all solutions contained (in $\mathrm{mM}$ ): $\mathrm{KCl} 5 ; \mathrm{MgCl}_{2} 2$; $\mathrm{CaCl}_{2}$ 1; Hepes 10; $\mathrm{pH}$ adjusted to $7.40 \pm 0.02$ with $\mathrm{NaOH}$. The osmolarity of solutions was determined using a freezing point osmometer (Knauer, Berlin, Germany). In each individual experiment, the mean cell volume of 10000 to 70000 cells was determined with a Z2 Coulter channelizer (Beckman-Coulter, Villepinte, France). Absolute cell volumes were obtained using beads (Coulter) as standards. The time resolution of this technique is low, in the order of $30 \mathrm{~s}$ to $1 \mathrm{~min}$. However, we previously showed that during an instantaneous

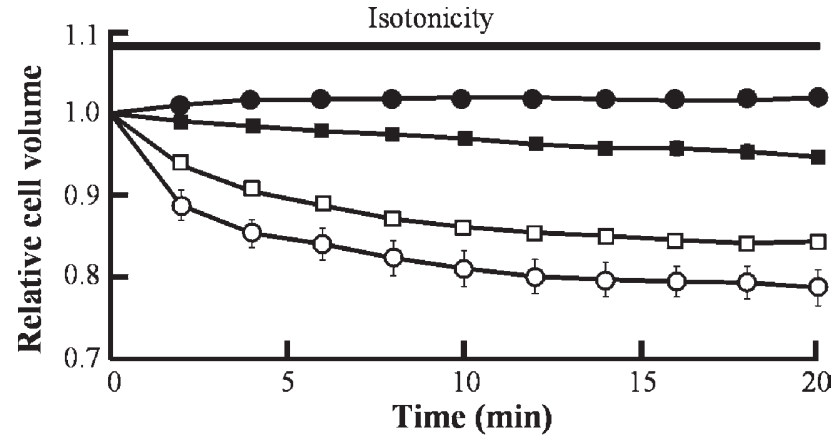

Figure 1. Evolution with time of the relative mean cell volume in isotonic solutions $\left(339 \mathrm{mOsm} \cdot \mathrm{kg}^{-1}\right)$. A few seconds after centrifugation, the cells were resuspended in solutions containing $160 \mathrm{mM}$ $\mathrm{NaCl}$ (filled squares), $165 \mathrm{mM} \mathrm{KCl}$ (filled circles), $80 \mathrm{mM} \mathrm{NaCl}+$ $150 \mathrm{mM}$ mannitol (open squares) or $160 \mathrm{mM} \mathrm{NMGCl}$ (open circles); $n=3-5$ in each condition.

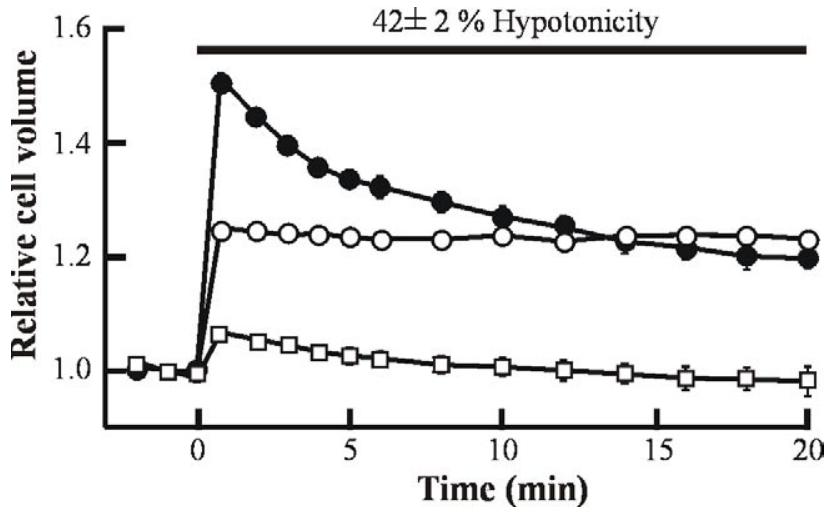

Figure 2. Time evolution of the relative mean cell volume during a $42 \pm 2 \%$ hypotonic challenge from 339 to $197 \mathrm{mOsm} \cdot \mathrm{kg}^{-1}$. The osmolarity was decreased in solution 1 by dilution with a $\mathrm{NaCl}$-free solution (filled circles) and in solution 2 by dilution with either a sucrose-free solution (open circles) or with a $\mathrm{NaCl}$ - and sucrosefree solution (open squares); $n=3-4$ in each condition; solution 1 : $160 \mathrm{mM} \mathrm{NaCl}$, solution 2: $80 \mathrm{mM} \mathrm{NaCl}+150 \mathrm{mM}$ sucrose.

anisotonic challenge, the maximal volume change of calceinloaded cells was also in the order of $1 \mathrm{~min}$ (Rouzaire-Dubois et al. 2009). Chemical reagents were from Sigma-Aldrich (Saint Quentin Fallavier, France). In each condition, cell volumes were expressed as the mean \pm the standard error of the mean (SEM) of $n$ experiments. The SEM was often smaller than $2 \%$ and consequently in the figures, the SEM bars were often smaller than the symbols.

\section{Results and Discussion}

In a first series of experiments, cell pellets were resuspended in different solutions, the osmolarity of which was identical to that of the culture medium $\left(339 \pm 2 \mathrm{mOsm} \cdot \mathrm{kg}^{-1}, n=17\right.$ and 15 , respectively). When the cells were resuspended in $\mathrm{NaCl}$ or $\mathrm{KCl}$ solutions, their volume was almost constant for $20 \mathrm{~min}$ (decreased by 4 to $5 \%$ in $\mathrm{NaCl}$ solution and increased by 1 to $2 \%$ in $\mathrm{KCl}$ solution). In contrast, when half of the $\mathrm{NaCl}$ was isosmotically substituted with mannitol or $\mathrm{NaCl}$ was isosmotically substituted with $\mathrm{NMGCl}$, the cell volume decreased by $16 \pm 0.01 \%$ and $21 \pm 2 \%$, respectively (Fig. 1). This was likely due to an efflux of $\mathrm{NaCl}$ and an associated water efflux against its osmotic gradient.

In order to test the idea that $\mathrm{H}_{2} \mathrm{O}$ could be actively transported in association with passive ion fluxes, we measured the relative volume changes of cells submitted to a $42 \pm 2 \%$ hypotonicity performed from two isotonic solutions (Rouzaire-Dubois et al. 2009) containing either $160 \mathrm{mM} \mathrm{NaCl}$ (solution 1) or $80 \mathrm{mM} \mathrm{NaCl}+150 \mathrm{mM}$ sucrose (solution 2). Fig. 2 clearly shows $\mathrm{NaCl}$-dependent 
deviation between the measured cell volume and the perfect osmometer. This confirms our recent results where, during hypotonicity, the cell volume was electronically measured or estimated from the fluorescence of calcein-loaded cells and was dependent on the net influx of $\mathrm{Na}^{+}$(RouzaireDubois et al. 2009). Altogether, these observations provide evidence that in addition to volume changes following the prediction of the Boyle-van't Hoff law of linearity between the relative cell volume and the relative inverse osmolarity, hyposmolarity also induces $\mathrm{Na}^{+}$-dependent water transport against its osmotic gradient. In other words, $\mathrm{H}_{2} \mathrm{O}$ could be transported by two mechanisms. The first one would be passive and depend on the $\mathrm{H}_{2} \mathrm{O}$ osmotic gradient. The second one would be associated with the net ion flux and could be opposite to the first one. To further confirm this conclusion, we measured the relative mean cell volume during $20 \%$ hypotonic challenges (from 339 to $271 \mathrm{mOsm} \cdot \mathrm{kg}^{-1}$ ) performed from isotonic solutions 1 or 2 by dilution with $\mathrm{NaCl}$-free solutions (Fig. 3a) As predicted, the cells swelled when hypotonicity was performed from isotonic solution 1 . $\mathbf{a}$

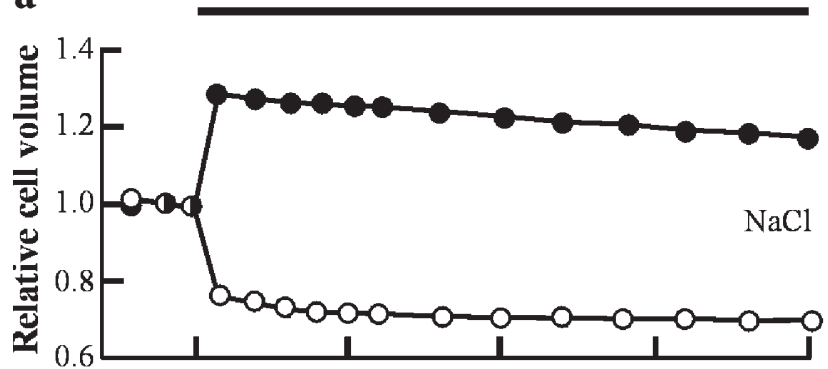

b

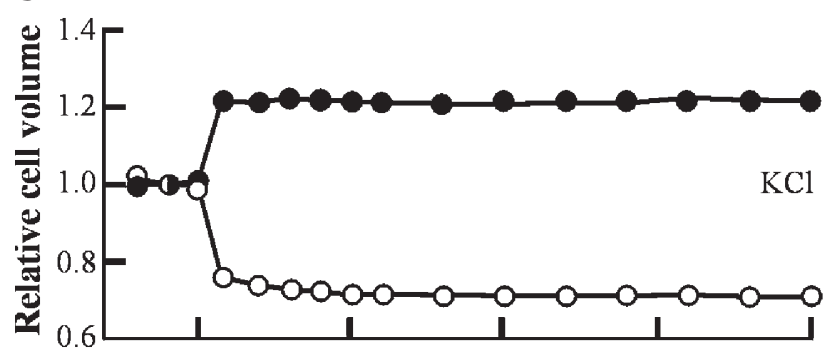

C

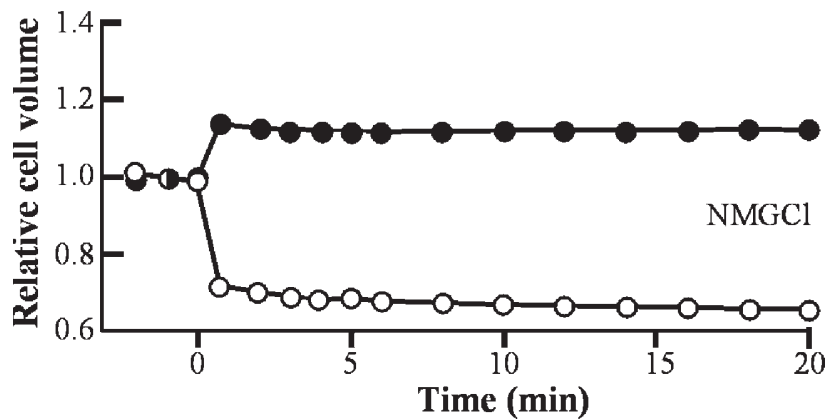

Figure 3. Hypotonicity can induce cell swelling or shrinkage. Isotonic solution 1 (filled symbols) contained $160 \mathrm{mM} \mathrm{NaCl}$ (a), $165 \mathrm{mM} \mathrm{KCl}$ (b) or $160 \mathrm{NMGCl}$ (c). Isotonic solution 2 (open symbols) contained $80 \mathrm{mM} \mathrm{NaCl}+150 \mathrm{mM}$ sucrose (a), $85 \mathrm{mM} \mathrm{KCl}+$ $150 \mathrm{mM}$ sucrose (b) or $80 \mathrm{mM} \mathrm{NMGCl}+150 \mathrm{mM}$ sucrose (c). In each condition, the osmolarity was decreased by $20 \pm 2 \%$ from 339 to $271 \mathrm{mOsm} \cdot \mathrm{kg}^{-1}$ with $\mathrm{NaCl}$-, KCl- or NMGCl-free solutions; $n=$ $3-4$ in each condition.
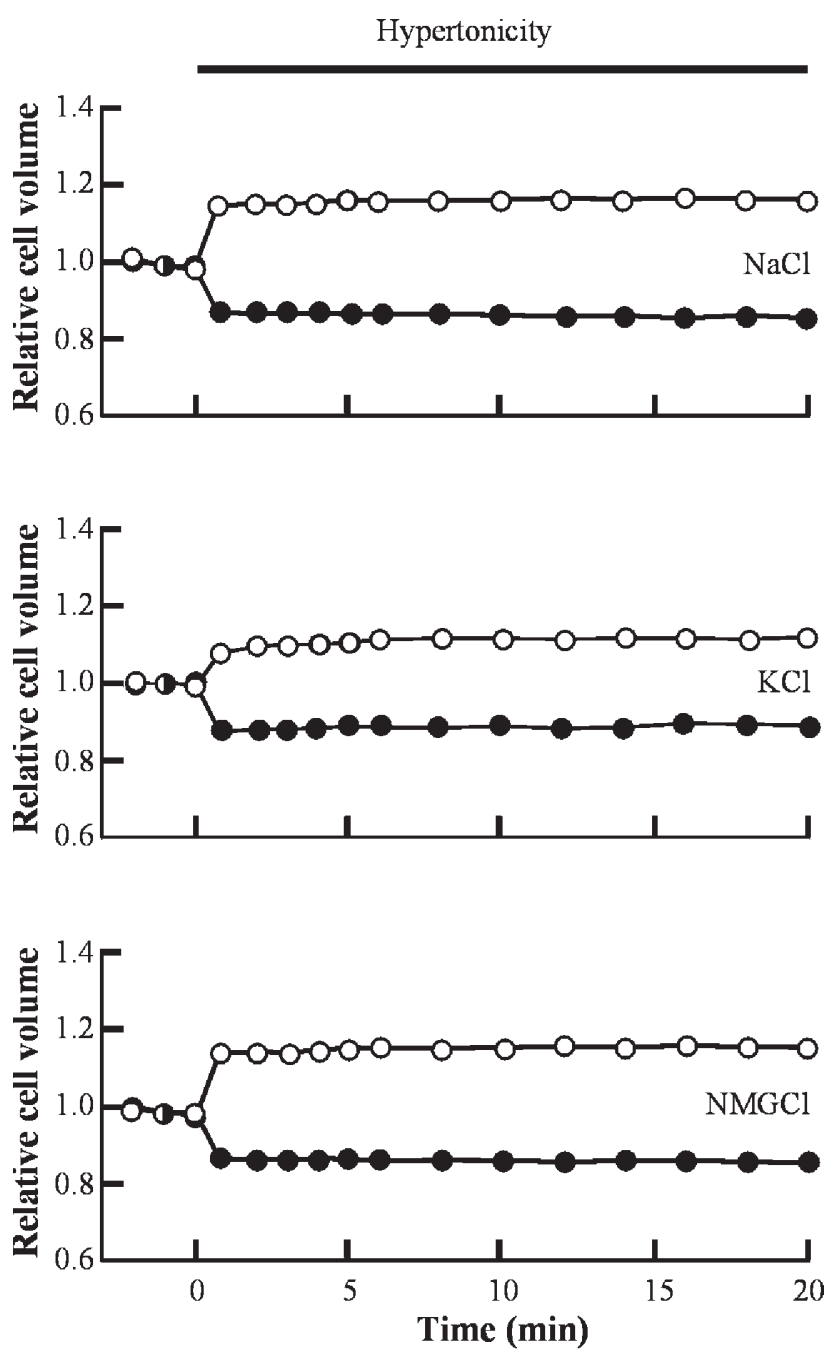

Figure 4. Hypertonicity can induce cell shrinkage or swelling. In a first series of experiments (filled circles), the isotonic solutions contained $160 \mathrm{mM} \mathrm{NaCl}$ (a), $165 \mathrm{mM} \mathrm{KCl} \mathrm{(b)} \mathrm{or} 160$ mM NMG$\mathrm{Cl}$ (c). In a second series of experiments (open circles), the isotonic solutions contained $300 \mathrm{mM}$ sucrose $+40 \mathrm{mM} \mathrm{NaCl}$ (a), or $45 \mathrm{mM}$ $\mathrm{KCl}$ (b) or $40 \mathrm{mM} \mathrm{NMGCl}$ (c). In each condition, the osmolarity was increased by $14 \%$ from 339 to $386 \mathrm{mOsm} \cdot \mathrm{kg}^{-1}$ by the addition of $20 \mathrm{mM} \mathrm{NaCl}, \mathrm{KCl}$ or NMGCl; $n=4$ in each condition. 
Unexpectedly, the cell shrank when the $\mathrm{NaCl}$ concentration in solution 2 was decreased from 80 to $40 \mathrm{mM}$. The same effects were observed when $\mathrm{NaCl}$ was substituted with $\mathrm{KCl}$ or NMGCl (Figs. 3b and c). These observations clearly show that when hypotonicity was induced by a decrease in electrolyte concentration from a low concentration of monovalent ions, the cell volume clearly decreased when it was expected to increase.

During hypotonicity, the cell shrinkage, observed when the external ion concentration was reduced (Fig. 3), implies an efflux of water against its osmotic gradient. This effect is not likely due to the activity of $\mathrm{K}^{+}-\mathrm{Cl}^{-}$or $\mathrm{Na}^{+}-\mathrm{K}^{+}-2 \mathrm{Cl}^{-}$cotransporters since their specific inhibitors dihydroindenyloxy-alkanoic acid (DIOA) and bumetamide had no effect (not shown).

As a corollary to the observations made during hyposmotic challenges, a $14 \%$ increase in hypertonicity could also induce either cell shrinkage or cell swelling, depending on the starting ion concentration in the isosmotic solutions (Fig. 4). As expected, the cells shrank when hyperosmolarity (from 339 to $386 \mathrm{mOsm} \cdot \mathrm{kg}^{-1}$ ) was induced from a physiological concentration of monovalent ions $(160 \mathrm{mM} \mathrm{NaCl}$ or $165 \mathrm{mM}$ $\mathrm{KCl}$ or $160 \mathrm{mM} \mathrm{NMGCl}$ ). In contrast, the cells swelled when the same hypertonic challenge was induced from a low concentration of monovalent ions $(40 \mathrm{mM} \mathrm{NaCl}$ or $45 \mathrm{mM} \mathrm{KCl}$ or $40 \mathrm{mM} \mathrm{NMGCl).} \mathrm{Once} \mathrm{again} \mathrm{this} \mathrm{shows} \mathrm{that} \mathrm{water} \mathrm{can}$ be transported against its osmotic gradient when coupled with passive ion fluxes.

Together, these observations raise the question as to how water is transported against its apparent osmotic gradient. During anisotonic challenges, $\mathrm{H}_{2} \mathrm{O}$ could be either passively transported due to the resulting changes in intracellular osmolarity or transported uphill in association with passive ion fluxes. In ion channels, $\mathrm{H}_{2} \mathrm{O}$ is present as hydration water of ions. According to the pore radius, one ion transports a maximum of 10 hydration $\mathrm{H}_{2} \mathrm{O}$ molecules (Carrillo-Tripp et al. 2006). When the concentration of $\mathrm{Na}^{+}$or $\mathrm{K}^{+}$but also the large ion $\mathrm{NMG}^{+}$was decreased or increased, the cell volume decreased or increased, respectively (Figs. 3 and 4, open circles). From these observations, we postulate that in addition to a passive transport through aquaporins (Rouzaire-Dubois et al. 2009) $\mathrm{H}_{2} \mathrm{O}$ should be actively co-transported with ions through non selective channels. Depending on the osmotic gradient of $\mathrm{H}_{2} \mathrm{O}$ and the electrochemical gradient of ions, these processes can be additive or opposite and can account for a deviation from the linear Boyle-vant't Hoff relationship between cell volume and inverse osmolarity. This new concept challenges the paradigm that $\mathrm{H}_{2} \mathrm{O}$ is exclusively transported according to its osmotic gradient and provides evidence that, independently of the activity of selective ion channels and transporters, the cell volume is dependent on both the external osmolarity and ion concentration gradients.
Acknowledgements. Authors thank Seana O’Regan for helpful discussion and critical reading of the manuscript.

\section{References}

Carrillo-Tripp M. L., San-Roman J., Hernandez-Cobos H., Saint-Martin H., Ortega-Blake I. (2006): Ion hydration in nanopores and the molecular basis of selectivity. Biophys. Chem. 124, 243-250; doi:10.1016/ j.bpc.2006.04.012

Charron F. M., Blanchard M. G., Lapointe J. Y. (2006): Intracellular hypertonicity is responsible for water flux associated with $\mathrm{Na}+$ /glucose cotransport. Biophys. J. 90, 3546-3554; doi:10.1529/biophysj.105.076745

Ernest N. J., Weaver A. K., Van Duyn L. B. Sontheimer H. W. (2005): Relative contribution of chloride channels and transporters to regulatory volume decrease in human glioma cells. Amer. J. Cell Physiol. 288, C1451-1460; doi:10.1152/ajpcell.00503.2004

Ernest N. J., Habela C. W., Sontheimer H. (2008): Cytoplasmic condensation is both necessary and sufficient to induce apoptotic cell death. J. Cell Physiol. 121, 290-297

Growe W. E., Altamirano J., Huerto L., Alvarez-Leefmans F. J. (1995): Volume changes in single N1E-115 neuroblastoma cells measured with a fluorescent probe. Neuroscience 69, 283-296; doi:10.1016/0306-4522(95)00219-9

Hamann S., Herrera-Perez J. J., Bundgaard M. F., Alvarez-Leefmans J., Zeuthen T. (2005): Water permeability of $\mathrm{Na}^{+}$$\mathrm{K}^{+}-2 \mathrm{Cl}^{-}$cotransporters in mammalian epithelial cell. J. Physiol. (London) 568, 123-135; doi:10.1113/jphysiol.2005.093526

Hoffmann E. K., Lambert I. C. H., Pedersen S. F. (2009): Physiology of cell volume regulation in vertebrates. Physiol. Rev. 89, 193-277; doi:10.1152/physrev.00037.2007

Lang F., Ritter M., Gamper N., Huber S., Fillon S., Tanneur V., Lepple-Wienhues A., Szabo I., Gulbins E. (2000): Cell volume in the regulation of cell proliferation and apoptotic cell death. Cell. Physiol. Biochem. 10, 417-428; doi:10.1159/000016367

Najvirtova M., Greer S. E., Greer M. A., Baqui L., Benicky J., Strbak V. (2003): Cell volume induced hormone secretion: studies on signal transduction and specificity. Cell. Physiol. Biochem. 13, 113-122; doi:10.1159/000070255

Okada Y., Sato K., Numata T. (2009): Pathophysiology and puzzles of the volume-sensitive outwardly rectifying anion channel. J. Physiol. (London) 587, 2141-2149

Rouzaire-Dubois B., Malo M., Milandri J. B., Dubois J. M. (2004): Cell size-proliferation relationship in rat glioma cells. Glia 45, 249-257

Rouzaire-Dubois B., Ouanounou G., O’Regan S., Dubois J. M. (2009): Sodium-dependent activity of aquaporin-1 in rat glioma cells: a new mechanism of cell volume regulation. Pflügers Arch. 457, 1187-1198; doi:10.1007/s00424-0080585-3

Soroceanu L., Manning T. J. Jr., Sontheimer H. (1999): Modulation of glioma cell migration and invasion using $\mathrm{Cl}^{-}$and $\mathrm{K}^{+}$ ion channel blockers. J. Neurosci. 19, 5942-5954 
Zeuthen T., Zeuthen E. (2007): The mechanism of water transport in $\mathrm{Na}+$-coupled glucose transporters expressed in Xenopus oocytes. Biophys. J. 93, 1413-1416; doi:10.1529/biophysj. 106.095380

Zeuthen T., Zeuthen E., Macaulay N. (2007): Water transport by GLUT2 expressed in Xenopus laevis oocytes. J.
Physiol. (London) 579, 345-361; doi:10.1113/jphysiol.2006.123380

Received: April 13, 2010

Final version acepted: June 11, 2010 